\title{
T Acute Lymphoblastic Leukemia
}

National Cancer Institute

\section{Source}

National Cancer Institute. I Acute Lymphoblastic Leukemia. NCI Thesaurus. Code C3183.

Acute lymphoblastic leukemia of T-cell origin. It comprises about $15 \%$ of childhood cases and $25 \%$ of adult cases. It is more common in males than females. (WHO, 2001) 